\title{
ポリエチレンフィルムの非線形粘弾性挙動*
}

$$
\begin{array}{lllllll}
\text { 木 村 } & \text { 博** } 山 \text { 口 } & \text { 拓 } & \text { 治** } \\
\text { 井 町 正 樹** 柳 川 } & \text { 昭 } & \text { 明** }
\end{array}
$$

\section{Nonlinear Viscoelastic Behavior of Polyethylene Films}

\author{
by \\ Hiroshi Kimura, Takuji Yamaguchi, \\ Masaki IMACHI and Teruaki YaNAGAwA \\ (Faculty of Engineering, Fukui University, Fukui)
}

In this paper, the adaptability of multiple integral equation of the constituents to nonlinear viscoelastic behaviors in uniaxial stretching, for two kinds of polyethylene having different crysta1linity, has been investigated. And the principle of a generalized superposition has been tested in respect of its stress relaxation, of its constant rate of elongation, and its two steps-stress relaxation experiments made by using only kernel functions $G_{1}(t), G_{2}(t, t), G_{3}(t, t, t), G_{4}(t, t, t, t)$.

The first kernel $G_{1}(t)$ is obtained from the data on nonlinear stress relaxation test, which agrees fairly well with the stress relaxation modulus in linear range. The calculated value of $G_{1}(t)$ from the relation between the stress and the strain rate in the constant rate of elongation test, also agrees with both the above mentioned values. These result mean that the superposition in the linear terms in the integral equation of the constituent holds true.

The behaviors under the two steps-stress relaxation tests depend strongly on the additional strain, and the effects of the first strain are irregular. These tendencies differ from the analytical results given out in the fourth order theory. Only the dependencies of input time of additional strain is, but quantitatively, qualitatively similar to the theory. Then, the fourth order theory in the integral equation of its constituent is not efficient enough to describe the complex nonlinear viscoelastic behaviors of polyethylene.

(Received Jan. 28, 1972)

\section{1 緒}

\section{言}

ボルッマンの重畳原理を仮定した線形粘弾性理論に より，無限小ひずみ領域の高分子の粘弾性挙動は充分 飞記述される。乙かし，結晶性高分子は比較的微小変 形で非線形粘弾性挙動が顕微であり，今日これらにつ いての研究が要請されている. 山口らは, ポリエチレ ンフィルムのひずみ $5 \%$ までの緩和弾性率が 20 ～100 ○の温度範囲に和いて，ひずみの一次式あるいは二次 式で充分近似できることを示した。この結果は, Green とRivlin の理論から出発した多重積分型構成方程式 を見かけ上満足し，核関数の一部が求められたことを 示す.しかし, 多重積分展開は広議の重畳原理であるの で, 直ちにこの結果が理論に一致したと認めることは

* 原稿受理 昭和47年 1 月28日

** 湢井大学工学部 福井市文京
できない，この型の構成方程式の適用の可否は，材料 の挙動の重疊性を検討する必要がある。結晶性高分子 に対して, 高次の重畳性を検討した研究は, Ward ら と Lifshitz と Kolsky の報告があるが, いずれもク リープ実験に応用したもので, 応力緩和実験に応用し た研究は見あたらない。構成方程式に含まれる核関数 の決定には，きわめて大きな労力を必要とするので, 本報では引数の異なる核関数の決定は行なわず，応力 緩和挙動々定速伸長挙動の間の関係, おょび二段応力 緩和挙動を重畳原理の観点より解析し, 多重積分型構 成方程式の適用性を検討する簡便な方法を求め，ポリ エチレンフィルムに対する実験結果との比較を行なう。

\section{2 解 析 方 法}

\section{$2 \cdot 1$ 構成方程式}

Pipkin は等方性でから非圧縮性物体の具体的な構 
成方程式を, 有限微小变形の場合について提出してい る.そこで提出された構成方程式は，テンソルを用い た三次元的なものであるが，本報で取り扱うような比 較的微小変形の一軸伸長に対しては, 中田の発表した 一次元構成方程式で充分近似できる。すなわる, 応力 を $\sigma(t)$ ひずみを

$$
\begin{aligned}
\sigma(t)= & \int_{-\infty}^{t} G_{1}\left(t-\tau_{1}\right) \frac{d \varepsilon}{d \tau_{1}} d \tau_{1} \\
& +\int_{-\infty}^{t} \int_{-\infty}^{t} G_{2}\left(t-\tau_{1}, t-\tau_{2}\right) \frac{d \varepsilon}{d \tau_{1}} \frac{d \varepsilon}{d \tau_{2}} d \tau_{1} d \tau_{2} \\
& +\int_{-\infty}^{t} \int_{-\infty}^{t} \int_{-\infty}^{t} G_{3}\left(t-\tau_{1}, t-\tau_{2}, t-\tau_{3}\right) \cdot \\
& \frac{d \varepsilon}{d \tau_{1}} \frac{d \varepsilon}{d \tau_{2}} \frac{d \varepsilon}{d \tau_{3}} d \tau_{1} d \tau_{2} d \tau_{3}+\cdots
\end{aligned}
$$

で与えられる.上式の各項は, 現在の応力がそれ以前 の $n$ 時点 $(n=1,2, \cdots)$ に扣けるひずみの相関として 与兄らることを示し，核関数 $G_{n}\left(t_{1}, t_{2}, \cdots, t_{n}\right)$ は 多時間高次緩和弾性率であり, $t_{\imath}<0$ のとき $G_{n}=0$ 之 なる.また $G_{n}\left(t_{1}, t_{2}, \cdots, t_{n}\right)$ は引数に関して対称性 を有している。

\section{$2 \cdot 2$ 応力緩和挙動}

$H(t)$ を単位階段関数とし, 入力 $\varepsilon(t)=\varepsilon_{0} H(t)$ を(1) 式に代入すると, 応力緩和弾性率は

$$
E(t)=G_{1}(t)+\varepsilon_{0} G_{2}(t, t)+\varepsilon_{0}^{2} G_{3}(t, t, t)+\cdots
$$

と $\varepsilon_{0}$ のベき級数になる.

\section{$2 \cdot 3$ 定速伸長挙動}

ひずみ速度を $v_{0}$ とすれば，大力 $\varepsilon(t)=v_{0} t H(t) を$ (1)式に代入して，

$$
\begin{aligned}
\sigma(t)= & v_{0} \int_{0}^{t} G_{1}\left(t-\tau_{1}\right) d \tau_{1} . \\
& +v_{0}^{2} \int_{0}^{t} \int_{0}^{t} G_{2}\left(t-\tau_{1}, t-\tau_{2}\right) d \tau_{1} d \tau_{2} \\
& +v_{0}^{3} \int_{0}^{t} \int_{0}^{t} \int_{0}^{t} G_{3}\left(t-\tau_{1}, t-\tau_{2}, t-\tau_{3}\right) \cdot \\
& d \tau_{1} d \tau_{2} d \tau_{3}+\cdots
\end{aligned}
$$

を得る.両辺を $v_{0}$ で除し，積分值を $t$ の関数で表わ すと

$$
\frac{\sigma(t)}{v_{0} \vec{I}}=F_{1}(t)+v_{0} F_{2}(t, t)+v_{0}^{2} F_{3}(t, t, t)+\cdots
$$

となり， $v_{0}$ のべき級数になる。

上式の $F_{\imath}$ と(2)式の $G_{\imath}$ の間には

$$
\begin{aligned}
& G_{1}(t)=\left.\frac{\partial F_{1}\left(t_{1}\right)}{\partial t_{1}}\right|_{t_{1}=t} \\
& G_{2}(t, t)=\left.\frac{\partial^{2} F_{2}\left(t_{1}, t_{2}\right)}{\partial t_{1} \partial t_{2}}\right|_{\substack{t_{1}=t \\
t_{2}=t}}
\end{aligned}
$$

などの関係がある，通常の定速伸長実験では， $t_{1}=t_{2}$ $=\cdots=t_{n}=t$ に和ける $F_{2}$ 乙か求まらないので，(5a) 式によって $G_{1}(t)$ しか求まらない.この方法で $G_{n}$ $(n>1)$ を求めるためには，伸長過程でひずみ速度を $(n-1)$ 回変速する $n$ 段定速伸長実験を行なう必要が
ある.（5 b )式は, 非線形領域の実験結果から線形項 を分離して, その領域の重畳性を検討する方法として 有用である。

\section{$2 \cdot 4$ 二段応力緩和挙動}

Fig. 1 を参照すると入力は,

$$
\varepsilon(t)=\varepsilon_{1} H(t)+\Delta \varepsilon H\left(t-t_{1}\right)
$$

で与えられ，上式を(1)式に代入して $\Delta \varepsilon$ の四次項まで とって, 二段ひずみ印加後の応力 $\sigma^{\prime}(t)$ と一段ひずみ 印加後の応力 $\sigma(t)$ の差 $\Delta(t)$ を近似計算すると,

$$
\begin{aligned}
\Delta(t)= & \Delta \varepsilon\left\{G_{1}\left(t-t_{1}\right)+2 \varepsilon_{1} G_{2}\left(t, t-t_{1}\right)\right. \\
& \left.+3 \varepsilon_{1}^{2} G_{3}\left(t, t, t-t_{1}\right)+4 \varepsilon_{1}^{3} G_{4}\left(t, t, t, t-t_{1}\right)\right\} \\
& +(\Delta \varepsilon)^{2}\left\{G_{2}\left(t-t_{1}, t-t_{1}\right)+3 \varepsilon_{1} G_{3}\left(t-t_{1},\right.\right. \\
& \left.\left.t-t_{1}, t-t_{1}\right)+6 \varepsilon_{1}^{2} G_{4}\left(t, t, t-t_{1}, t-t_{1}\right)\right\} \\
& +(\Delta \varepsilon)^{3}\left\{G_{3}\left(t-t_{1}, t-t_{1}, t-t_{1}\right)\right. \\
& \left.+4 \varepsilon_{1} G_{4}\left(t, t-t_{1}, t-t_{1}, t-t_{1}\right)\right\} \\
& +(\Delta \varepsilon)^{4}\left\{G_{4}\left(t-t_{1}, t-t_{1}, t-t_{1}, t-t_{1}\right)\right\}
\end{aligned}
$$

となる。

$\Delta \varepsilon>0$ の場合, $\Delta(t) \equiv \Delta_{+}(t), \Delta \varepsilon<0$ の場合に $\Delta(t)$ $\equiv \Delta_{+}(t)$ で表わし， $\Delta_{+}(t)>0, \Delta_{-}(t)<0$ を考慮し, さらに, $t^{\prime}=t-t_{1}$ と和いて, 上式の奇数次項を消去す ると

$$
\begin{aligned}
R\left(t^{\prime}\right) \equiv & -\frac{\left\{\Delta_{+}(t)+\Delta_{-}(t)\right\}}{2(\Delta \varepsilon)^{2}}=\frac{\left\{\left|\Delta_{-}(t)\right|-\left|\Delta_{+}(t)\right|\right\}}{2(\Delta \varepsilon)^{2}} \\
= & -\left\{G_{2}\left(t^{\prime}, t^{\prime}\right)+3 \varepsilon_{1} G_{3}\left(t^{\prime}+t_{1}, t^{\prime}, t^{\prime}\right)\right. \\
& +6 \varepsilon_{1}{ }^{2} G_{4}\left(t^{\prime}+t_{1}, t^{\prime}+t_{1}, t^{\prime}, t^{\prime}\right) \\
& \left.+(\Delta \varepsilon)^{2} G_{4}\left(t^{\prime}, t^{\prime}, t^{\prime}, t^{\prime}\right)\right\}
\end{aligned}
$$

となる。

線形の場合, $|\Delta+(t)|=|\Delta-(t)|$ で $R(t)=0$ となる ことは周知のことである. 二重積分近似では, $R(t)$ は 一段ひずみ $\varepsilon_{1}$, 付加ひずみ $\Delta \varepsilon$ ，和よび二段ひずみ印 加時刻 $t_{1}$ に依存せず， $-G_{2}(t, t)$ となる. 本報で用い た材料は $G_{2}(t, t)<0$ であり, $\left|G_{2}(t, t)\right|$ は $t$ の単調減 少関数であるから, 二重積分近似の場合は, $\left|\Delta_{-}(t)\right|$ $>\left|\Delta_{+}(t)\right|$ となり, $R(t)$ は $t$ に対して単調減少する。 三重積分近似の場合には， $\varepsilon_{1}$ と $t_{1}$ に依存するが， $\Delta \varepsilon$ には依存しない，四重積分近似でさらに $\Delta \varepsilon$ 依存性が 現われる。

応力緩和実験より， $G_{2}(t, t)$ と $G_{4}(t, t, t, t)$ が求ま るから，
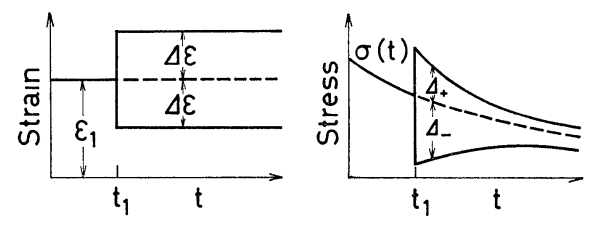

Fig. 1. Diagram of two step stress relaxation program and response. 


$$
\begin{aligned}
P\left(t^{\prime}\right) & \equiv \frac{R\left(t^{\prime}\right)+G_{2}\left(t^{\prime}, t^{\prime}\right)+(\Delta \varepsilon)^{2} G_{4}\left(t^{\prime}, t^{\prime}, t^{\prime}, t^{\prime}\right)}{3 \varepsilon_{1}} \\
& =\frac{1}{6(\Delta \varepsilon)^{2} \varepsilon_{1}}\left\{\left|\Delta_{-}(t)\right|-\left|\Delta_{+}(t)\right|\right. \\
& \left.+2(\Delta \varepsilon)^{2} G_{2}\left(t^{\prime}, t^{\prime}\right)+2(\Delta \varepsilon)^{4} G_{4}\left(t^{\prime}, t^{\prime}, t^{\prime}, t^{\prime}\right)\right\} \\
& =-\left\{G_{3}\left(t^{\prime}+t_{1}, t^{\prime}, t^{\prime}\right)\right. \\
& \left.+2 \varepsilon_{1} G_{4}\left(t^{\prime}+t_{1}, t^{\prime}+t_{1}, t^{\prime}, t^{\prime}\right)\right\}
\end{aligned}
$$

の左辺は計算することができる. 右辺で $\Delta \varepsilon$ 依存性が 消失し, $\varepsilon_{1}$ の一次式となり, $G_{3}\left(t^{\prime}+t_{1}, t^{\prime}, t^{\prime}\right), G_{4}\left(t^{\prime}+t\right.$, $\left.t^{\prime}+t_{1}, t^{\prime}, t^{\prime}\right)$ を求めることができる。 二重積分近似で は $P(t)=0$ となり, 三重積分近似の場合は， $\varepsilon_{1}$ の影 響はない。

一般に, $t_{\imath} \geqslant 0$ で $s_{\imath}=t+t_{\imath}(i=1,2, \cdots, n)$ とすれば, $G_{n}\left(s_{1}, s_{2}, \cdots, s_{n}\right)$ は $G_{n}(t, t, \cdots, t)(n>1)$ 之余り大 差ないと仮定し，また $t$ が $t_{2}$ に比して大きくなれば, $t_{1}$ の影響が薄れ, $G_{n}\left(s_{1}, s_{2}, \cdots, s_{n}\right)$ は $G_{n}(t, t, \cdots, t)$ に 収れんとすると仮定すると，次のように書くことがで きる。

$G_{n}\left(s_{1}, s_{2}, \cdots, s_{n}\right)=f_{n}\left(s_{1}, s_{2}, \cdots, s_{n}\right)+G_{n}(t, t, \cdots, t) \quad$ (10) 収れんの条件により， $t \geqslant \max \left(s_{\imath}-t\right)$ で， $f_{n}$ は 0 に なる。あるいは,

$G_{n}\left(s_{1}, s_{2}, \cdots, s_{n}\right)=g_{n}\left(s_{1}, s_{2}, \cdots, s_{n}\right) \times G_{n}(t, t, \cdots, t)$ (11)

この場合には, $t \geqslant \max \left(s_{2}-t\right)$ で $g_{n}$ は 1 になる。

$f_{n}, g_{n}$ は引数がすべて等しい場合に，それぞれ0， 1 になる以外は, 対称性, 因果律を満足するなどの性 質は $G_{n}$ の性質と同一である。(11)，(12)式のいずれを採 用した方が有利であるかは，実験值の処理の際，ある いは理論展開に応用する際に判断される，以上の仮定 から, $P\left(t^{\prime}\right)$ は $-\left\{G_{3}\left(t^{\prime}, t^{\prime}, t^{\prime}\right)+2 \varepsilon_{1} G_{4}\left(t^{\prime}, t^{\prime}, t^{\prime}, t^{\prime}\right)\right\} に$ 収れんする。このように $R(t)$ あるいは $P(t)$ を求め て, 多重積分展開した場合の高次の項の重畳性を検討 することができる。

$$
3 \text { 実験 }
$$

\section{$3 \cdot 1$ 試料}

用いた試料は，低密度ポリエチレン Yukalon K3212 (三菱油化 K. K. 製) および高密度ポリェチレン Hizex $5000-\mathrm{S}$ (三井石油化学K.K. 製) の二種類であ る。試料の製膜条件, 密度㘧よび結晶化度を Table I に示す. 厚みは約 $0.3 \sim 0.4 \mathrm{~mm}$ であった。

\section{$3 \cdot 2$ 測定}

これらの試料を長さ $10 \mathrm{~cm}$, 幅 $1 \mathrm{~cm}$ の短ざく型に 切り,テーブル型インストロン試験機(MODEL TMM) を用い, チャック間距離 $5 \mathrm{~cm}$ とした. Table II に定速伸長実験に用いた伸長速度とひず㕛速度の関係 を示す。測定時間は, 最低伸長速度で 3000 秒, 最高 伸長速度で 4 秒とし，最大伸長ひずみは 4 〜 $10 \%$ とし た. Table III に二段応力緩和実験に採用した一段ひ ずみ $\varepsilon_{1}$, 付加ひずみ $\Delta \varepsilon$, 二段ひずみ印加時刻 $t_{1}$ を示

\begin{tabular}{|c|c|c|c|c|}
\hline $\begin{array}{cc}v & v_{0} \\
(\mathrm{~cm} / \mathrm{min}) & (1 / \mathrm{sec})\end{array}$ & $\left(\begin{array}{c}v \\
(\mathrm{~cm} / \mathrm{m} 1 \mathrm{n})\end{array}\right.$ & a) $(1 / \mathrm{vec})$ & $\stackrel{v}{v}(\mathrm{~cm} / \mathrm{m} 1 \mathrm{n}$ & n) $\stackrel{v_{0}}{(1 / \mathrm{sec})}$ \\
\hline $0004 \quad 133 \times 10^{-5}$ & 005 & $166 \times 10^{-4}$ & 08 & $2.66 \times 10^{-3}$ \\
\hline 0.005166 & 008 & 266 & 1.0 & 333 \\
\hline 0008266 & 01 & 333 & 1.333 & 4.44 \\
\hline $\begin{array}{llll}0 & 01 & 3 & 33\end{array}$ & 0133 & 444 & 20 & 666 \\
\hline $0013 \quad 444$ & 0.2 & 666 & 30 & $1.00 \times 10^{-2}$ \\
\hline $002 \quad 666$ & 0.3 & $1.00 \times 10^{-3}$ & 4.0 & 133 \\
\hline $0.03 \quad 1.00 \times 10^{-4}$ & 0.4 & 1.33 & 5.0 & 166 \\
\hline $0.04 \quad 133$ & 05 & 1.66 & 8.0 & 2.66 \\
\hline
\end{tabular}

Table I. Casting conditions, density, and degree of crystallinity of the polyethylene films tested.

\begin{tabular}{c|l|c|c}
\hline Sample & \multicolumn{1}{|c|}{ Casting } & $\begin{array}{l}\text { Density } \\
\left(\mathrm{g} / \mathrm{cm}^{2}\right)\end{array}$ & $\begin{array}{l}\text { Degree of } \\
\text { crystal- } \\
\text { linity (\%) }\end{array}$ \\
\hline $\begin{array}{l}\text { Yukalon } \\
\mathrm{K}-3212\end{array}$ & $\begin{array}{l}\text { Melted at } 140^{\circ} \mathrm{C} \text { for } 10 \mathrm{~min}, \\
\text { cooled gradually, kept at } \\
105^{\circ} \mathrm{C} \text { for } 1 \mathrm{hr} \text {, cooled } \\
\text { gradually again down to } \\
\text { room temperature, and } \\
\text { conditioned at } 105^{\circ} \mathrm{C} \text { for } \\
\text { 2hr. }\end{array}$ & 0.922 & 66.2 \\
\hline Hizex & $\begin{array}{l}\text { Melted at } 180^{\circ} \mathrm{C} \text { for } 10 \mathrm{~min}, \\
\text { cooled gradually, kept at } \\
125^{\circ} \mathrm{C} \text { for } 1 \mathrm{hr}, \mathrm{cooled} \\
\text { gradually again down to } \\
\text { room temperature, and } \\
\text { conditioned at } 125^{\circ} \mathrm{C} \text { for } \\
2 \mathrm{hr} \text {. }\end{array}$ & 0.969 & 897 \\
\hline
\end{tabular}

\begin{tabular}{|c|c|c|c|c|c|c|}
\hline \multicolumn{3}{|c|}{ Yukalon } & \multicolumn{4}{|c|}{ Hizex } \\
\hline$\varepsilon_{1}(\%)$ & \multicolumn{2}{|c|}{$\Delta \varepsilon(\%)$} & $\varepsilon_{1}(\%)$ & \multicolumn{3}{|c|}{$\Delta \varepsilon(\%)$} \\
\hline 03 & 0 05, & $0.1, \quad 015$ & 03 & 0.05 & 0.1 , & 0.15 \\
\hline 10 & 05 & & 0.7 & 0.10 & 0.2 , & 0.4 \\
\hline 2.0 & 05 , & 10 & 1.0 & 020 & 0.4 , & 0.6 \\
\hline 30 & 05 & $10, \quad 1.5$ & 20 & 0.20 & 04 , & 06 \\
\hline$t_{1}(\mathrm{sec})$ & 100 & $200, \quad 500$ & & & & \\
\hline
\end{tabular}

Table II. Cross head speed $v$ and strain rate $v_{0}$ used in constant rates of elongation.

Table III. F1rst strain $\varepsilon_{1}$, additional strain $\Delta \varepsilon$, and input time used in two step relaxation.

す. 実験はすべて $20^{\circ} \mathrm{C} ， 65 \% \mathrm{RH}$ の恒温恒湿室で行な った。

\section{$4 \cdot 1$ 応力緩和挙動}

\section{4 実験結果および考察}

Fig. 2 飞緩和弾性率の等時曲線の一例を示す。図よ り明らかなように、ひずみの増加にしたがって, 弾性 率は低下し，(2)式のよらにひずみのべき級数で表わす ことができる．これをひずみの三次式で近似して $G_{n}$ を求めると, $n=1,3$ の場合, $G_{n}>0, n=2,4$ の場合 $G_{n}<0$ となり, 応力緩和弾性率は $\varepsilon_{0}$ の交代級数にな る. $\varepsilon_{0}<1$ の範囲では

$$
\varepsilon_{0}^{n-1} G_{n}(t) \geqslant \varepsilon_{0}^{n} G_{n+1}(t)
$$




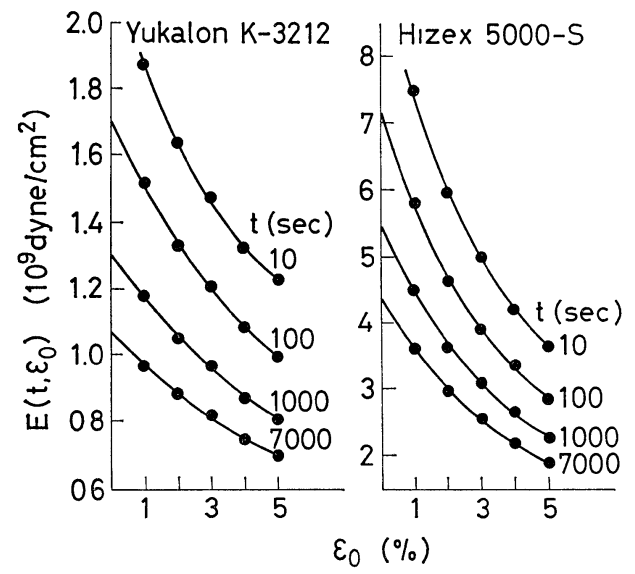

Fig. 2. Isochronous stress relaxation modulus plotted against the strain.

であれば，級数は収れんする。 $\varepsilon_{0}$ が $5 \%$ までの範囲で， 上式の条件は満足していた。 Fig. 3 は $\log \left|G_{n}\right|$ を $\log t$ に対してプロットしたものである。低密度試料の場合 は, 時間の経過とともに高次の $G_{n}$ の寄与が減少して,

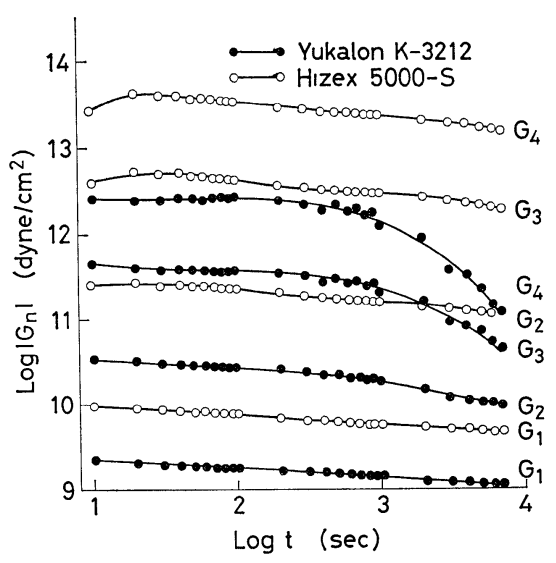

Fig. 3. Kernel functions $G_{1}(t), G_{2}(t, t), G_{3}(t, t, t)$, $G_{4}(t, t, t, t)$ versus time for pure tension.
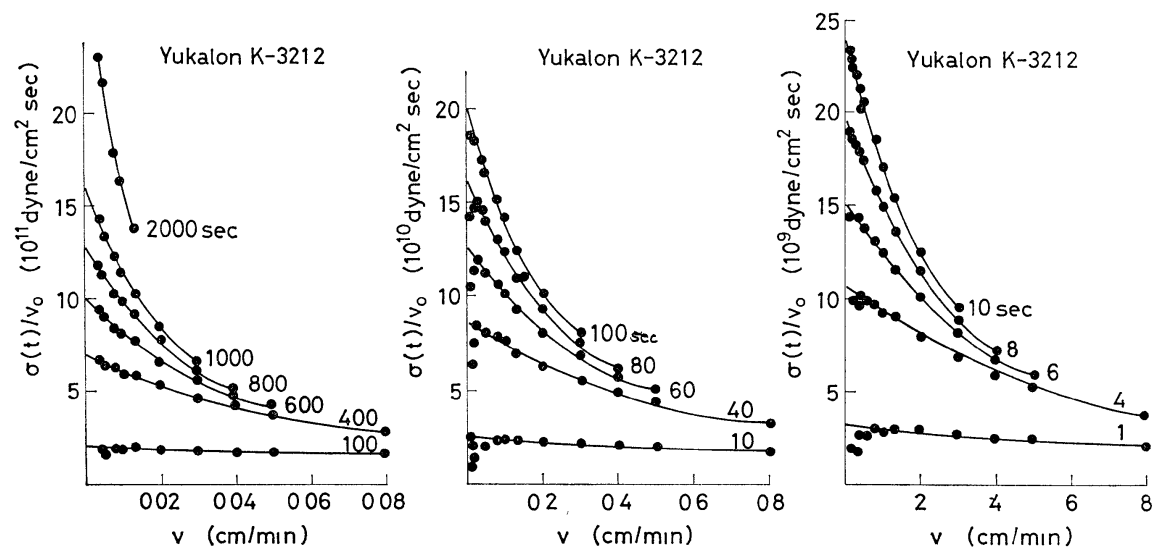

Fig. 4. Isochronous tensile stress/strain rate plotted against the rate of elongation for low density polyethylene.
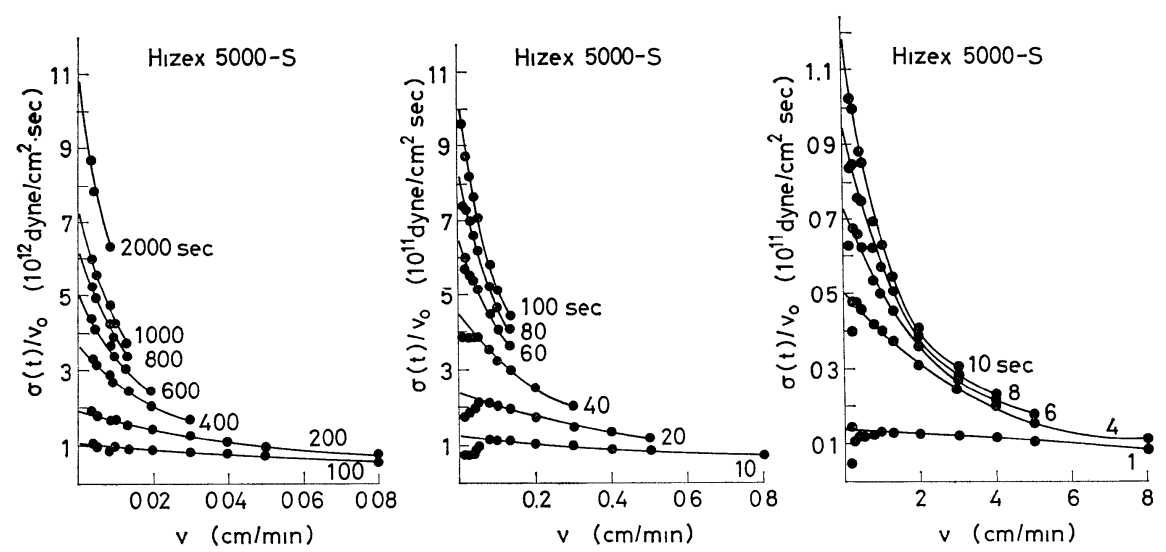

Fig. 5. Isochronous tensile stress/strain rate plotted against the rate of elongation for high density polyethylene. 
えられる。

\section{$4 \cdot 2$ 等速伸長挙動}

Fig. 4 と Fig. 5 は $\sigma(t) / v_{0}$ の等時曲線を示したもの で, 伸長速度の増加にしたがって， $\sigma(t) / v_{0}$ は減少し 顕著な非線形を示し，(4)式のようにひずみ速度のべき 級数で表わすことができる。しかし，高速伸長の短時 間域の実測值は減少曲線からはずれ，逆に伸長速度の 増加にしたがって， $\sigma(t) / v_{0}$ の值は増加している。 こ の原因は明確でないが，大体ひずみ $0.5 \%$ までにこの 現象が見られることから, 複雑な微細構造の変形, 破 壞に基ら゙くもの之考光られる。図中の曲線は， $v_{0}$ の三 次曲線で近似したものである。(4)式の $F_{n}$ は $G_{n}$ 之同 様に，nが奇数の場合正で，偶数の場合負となり， $\sigma(t) / v_{0}$ は $v_{0}$ の交代級数となる. Fig. 6 は $\log \left|F_{n}\right|$ と $\log t$ の関係を示したものである。低密度試料の $\log F_{1}$ と, 高密度試料のすべての $\log \left|F_{n}\right|$ が注注直線状に変 化していることは，(5)式の関係を定性的に満足してい ることを示している。

Fig.7 は(5a)式によって求めた $G_{1}(t)$ と(2)式の $G_{1}(t)$ 特よび線形領域の緩和弾性率を比較したものである. 両試料とも, 三本の曲線は良好な一致を示している。 したがって, 両試料とも(1)式の線形項の重盢性を満足 していると考觉られる。

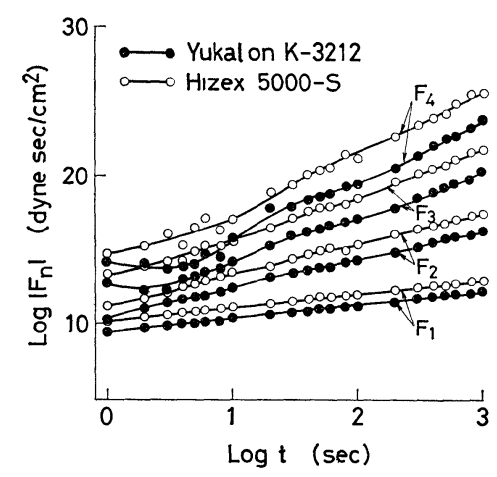

Fig. 6. $F_{n}(t, \ldots, t)$ in Eq. (4) versus time curves obtained by constant rates of elongation.

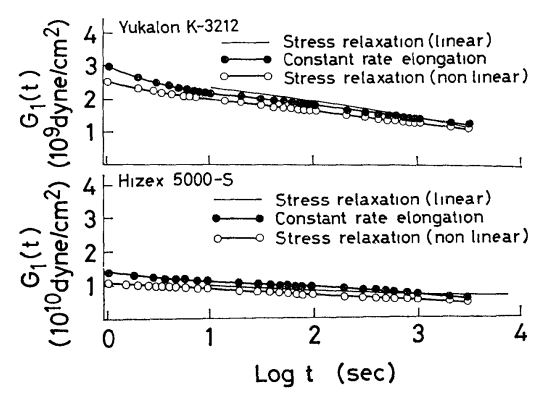

Fig. 7. Comparison of the linear stress relaxation modulus with $G_{1}$ obtained by Eq. (2) and Eq. (5.a).
な特, 図中の非線形領域の応力緩和実験から求めた $G_{1}(t)$ の短時間側 $(1 \sim 100 \mathrm{sec})$ の值は, $10^{\circ} \mathrm{C} の G_{1}(t)$ 曲線を $\log t$ 軸に沿って移動し, $20^{\circ} \mathrm{C} の G_{1}(t)$ 曲線に 重ね合わせて得たるのである.

\section{$4 \cdot 3$ 二段応力緩和挙動}

$P(t)$ 曲線の代表例をFig. 8,9 亿示す. $\varepsilon_{1}=0.3 \%$ の 場合は, 測定値の誤差が大きく系統的な結果が得られ なかったが，そ礼以外の $\varepsilon_{1}$ に対する $P(t)$ 曲線の傾 向はこの図に類似している。 $\Delta \varepsilon$ が小さい場合, 実測 值がばらついているのは， $P(t)$ の誤差はいろいろの 量の誤差が集積されて大きくなるためである.

これらの図を通じて共通なことは， $\Delta \varepsilon$ が大きいほ ぞ, $P(t)$ の值が小さくなり，明りょうな $\Delta \varepsilon$ 依存性 が表われていることである。この $\Delta \varepsilon$ 依存性は短時間 領域で著しく, 時間の経過とともに減少していく。こ

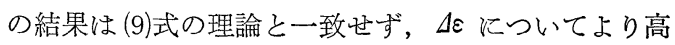
次の非線形を示す。 $(\Delta \varepsilon)^{2} G_{4}(t, t, t, t)$ の $P(t)$ への寄 与が小さいので,さらに高次の項を加光ても, $P(t) の$ $\Delta \varepsilon$ 依存性を記述できる可能性は余り期待できないと 思われる。

$P(t)$ と $\varepsilon_{1}$ の一次関係を, Yukalon 試料で $\Delta \varepsilon=0.5$ $\%$, Hizex 試料で $\Delta \varepsilon=0.2 ， 0.4 \%$ 結果について調
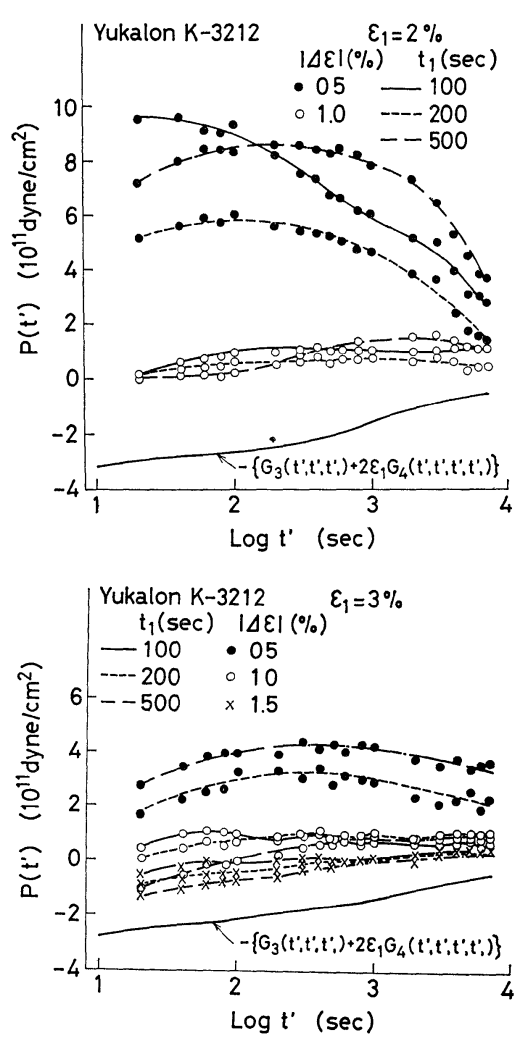

Fig. 8. Effects of additional strain $\Delta \varepsilon$ and input time of $\Delta \varepsilon$ on $P\left(t^{\prime}\right)$ in two step relaxation test for low density polyetylene. 

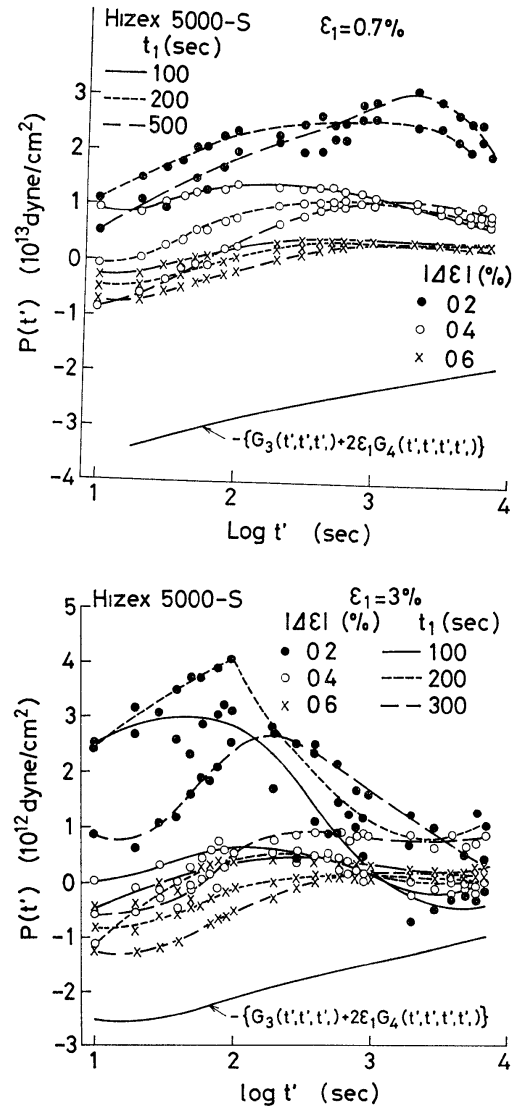

Fig. 9. Effects of additional strain $\Delta \varepsilon$ and input time of $\Delta \varepsilon$ on $P\left(t^{\prime}\right)$ in two step relaxation test for high density polyethylene.

べたが， $P(t)$ と $\varepsilon_{1}$ の間に系統的な関係は認められず, この点でも実測值は理論と一致しない。

$t_{1}$ の影響については, 全般的傾向として $P(t)$ は短 時間領域で増加し，その増加速度は $t_{1}$ の大きいもの ほど大きい,一方, 長時間領域では, $P(t)$ は漸増, 平 衡, 減少の三つの挙動に分かれる。この挙動と $\Delta \varepsilon, t_{1}$, $\varepsilon_{1}$ の間には定まった関係以認められないが， $t_{1}$ の影響 が次第に薄れ， $P(t)$ はある一定值に収れんする傾向 があり，(10)，(11)式の仮定と一致する。しかし図中の理 論的収れ几值 $-\left\{G_{3}(t, t, t)+2 \varepsilon_{1} G_{4}(t, t, t, t)\right\}$ と比較す
ると，実測值はかなり大きい，その理由は，(9)式に䄺 いて $G_{2}(t, t)$ と $G_{4}(t, t, t, t)$ が負であることを考虑す れば， $\left|\Delta_{-}\right|$が $\left|\Delta_{+}\right|$に比して大きくなるためと思われ る. $\Delta \varepsilon$ が小さい場合に，この傾向が著しいので，初 期の除荷で荷重の低下が顕著で，次第にその低下が鈍 下する除荷経路が推測される。このような除荷経路は 塑性ヒステレシス曲線に执いて見られることから，塑 性ひずみが存在するため，実験が理論に一致しない一 因とも考光られる。

以上, 厳密な解析によって, 実測值は高次の重畳性 を満足しないことが明らかになった，前述のょうに， より高次の近似を行なっても, 理論と実験の一致を求 めることは困難と考克ら机る。 むしろ, 三次元的取り 扱い, $G_{n}$ の対称性, 定常性などの検討, 塑性を考慮 するなどを行なって，逆に低次の近似で充分記述する ような理論を案出する方が望ましいように思われる。

終わりに，本研究に対し，有益なご助言をいただい た京都大学工学部河合弘廸教授, 川端季雄助教授飞感 謝を表し，あわせて，実験の一部を協力された鹿島高 広氏に謝意を表します。

（昭和46年10月20日 第19回レオロジー討論会にて講演）

\section{参 考 文 献}

1）山口拓治, 高橋哲夫, 柳川昭明, 木村里雄, 繊維学会誌, 27, 65 (1971).

2) Green, A.E., and R. S. Rivlin, Arch. Rat. Anal., 1, 1 (1957).

3) Green, A. E., R. S. Rivlin, and A. J. M. Spencer, Arch. Rat. Anal., 3, 82 (1959).

4) Pipkin, A.C., Rev. Mod. Phys., 36, 1034 (1964).

5) Nakada, O., J. Phys. Soc. Japan, 15, 2880 (1960).

6) Ward, I M., and E T. Onat, J. Mech. Phys. Solids, 11, 217 (1963).

7) Hodley, D. W., and I. M. Ward, əbrd., 13, 397 (1965).

8) Ward, I. M., and J.M. Wolfe, ibzd., 14, 131 (1966).

9) Lifshitz, J. M., and H. Kolsky, Int. J. Solids Structures, 3, 383 (1967).

10) Lokett, F. J., Int. J. Engng. Sci, 3, 59 (1965).

(458頁より)

250. Viskoelastisches und Gleichgewichtsverhalten des ingeringem Grad vernetzten Poly(2-Hydroxyäthylmethacrylates) im kautschukartigen Zustand, J. Janáček, 262.

251. On the stability of viscoelastic fluid flow, IV, A. Giesekus, R. K. Bhatnagar, 266.

252. Anlaufmessungen an Polyvinylacetal-Losungen, J. Schurz, A. Mavrommatakos, 275.

253. Stromungsdoppelbrechung in Kaolinsuspensionen, D. Hums, R. Bruckner, 289.

254. Dynamisches Verhalten von Elastomeren bei grossen Dehnungen uderlagerten kleinen Schwingungen, E. A. Meinecke, 302.

255. Analysis of dynamical behavior of viscoelastic fluids, C. D. Han, 326.

256. Stochastic models of relaxation phenomena, D. R. Axelrad, J.Provan, 330.

257. High-elasticity of polyisobutylene and polystyrene solutions, A. Y. Malkin, M.P.Zabugina, V.E. Drevad, G. V. Vinogradov, 336.

(475頁へ) 